\title{
Perspectives on Higher Education and the Labor Market Outcomes in Nigeria
}

\author{
Dr. Roseline 0. Osagie \\ University of Benin, Faculty of Education, \\ Benin City- Edo State Nigeria \\ Email : rosarugue@yahoo.co.uk
}

\section{Doi:10.5901/jesr.2014.v4n3p125}

\begin{abstract}
This study examines the role of higher education in improving labor market outcomes with a particular focus on public policy considerations in Nigeria. One important institution the labor market relies on for the production of high level manpower is the university. This is so because of the link between higher education knowledge and business practice. The study found that government policies need to be seen within a broader macroeconomic context if higher education is to contribute to national economic growth. The study also found that policies aimed at improving the skills of the workforce will have limited impact on the national economy unless there is a place in the labor market that demands those skills. This study recommends among others, agriculture, infrastructure construction for both rural and urban geography, manufacturing, international partnership for employment creation for higher education graduates in the labor market.
\end{abstract}

Keywords: Higher education, labor market, public policy, infrastructure, Nigeria

\section{Introduction}

Higher education plays a central role in preparing individuals to enter the labour market as well as equipping them with the skills to engage in lifelong learning experiences ( Fasih, 2008). Education is the main tool for impacting skills and attitudes relevant to the contribution of the individual concerned to national development. Education trains manpower for the national economy, helps to develop the potentials of individuals and help such individuals consummate employment opportunities in the labour market (Ali, 1988). Thus, formal education ideally enhances labour market participation of graduates since higher education is a critical variable in modern work situations. Furthermore, higher education broadens the experience of graduates and gives them access to new resources and skills (Stephen, 1992). These ideal aims of education are fulfilled for employment and use the opportunity of employment to make various contributions toward the development of the society. Therefore, education acquired is only relevant to the extent it makes noticeable impact in the lives of the individuals and society (Anugwon, 2009).

Education generally is concerned with imparting knowledge in people. Knowledge in this case can be viewed as a series of instructions and social ethos which hinge on the acquisition of abstract ideas which makes for a refined mind and the acquisition of psycho-motor skills, which in turn makes for a skilled person or at least positions one in the right frame of mind to acquire the skill necessary for existence in an atomized social order (Anugwon, 2009). Hence, education is a social tool that is an imperative for the survival and growth of the human society. Thus, education whether formal or informal bears an important social context. The educational system is an elaborate social mechanism designed to bring about in persons submitted to it certain skills and attitudes judged to be useful and desirable in the society (Connor, 1957). This implies that education derives from the social system and exists mainly to satisfy the demands of the society system.

Thus, education produces the workforce needed to keep the labor market operational. Education then contributes in measurable terms to the economic development when those educated submit themselves to work in the labor market. It is because of this usefulness that UNESCO (2008) recommended that developing countries should allocate 26 per cent of their yearly budget to education. Nigeria has not been able to meet up with this recommendation because of the other sectors of the economy competing for the resources of the government. Tertiary education plays a very important role in the economic and political stability of any nation because it is this level of education that supplies the highest percentage of the much needed human capital for any form of development, be it economic, social or political. Due to the prominent role higher education plays, sixty per cent of the yearly budget to education is allocated to tertiary education in Nigeria ( Balami, 2003). This is to enable it meet the goals of the tertiary institutions as stated in the National Policy on Education 
(2004), tertiary education is expected to among others to contribute to national development through high level relevant manpower training. Thus, education is knowledge gained and knowledge used to affect the immediate environment Education is not about having knowledge but knowing what to do with the knowledge acquired ( Ize-Omoregie, 2013).

The general objective of this paper is to investigate the role of higher education, in particular, university education in improving labor market outcomes in Nigeria and how public policy affects the linkage between higher education and the labor market.

\section{Objectives of the Study}

The main objective of the study is to ascertain the role of higher education in improving the labor market outcomes and how public policy affects the market, in particular, the generation of graduate employment in Nigeria.

\section{Significance of the Study}

The generation of employment opportunities is an imperative to rapid and sustainable economic development in the labor market in Nigeria. Higher education and relevant skills are necessary conditions for good labor market outcomes for individuals. The understanding of the impact of public policies to employment generation is crucial for a country such as Nigeria. This study considers these issues in the light of Nigerian experience and policy regimes that have existed. This study unlike others recognizes that public policies have implications for economic growth as well as employment generation in the labor market.

\section{Methodology}

he study adopted the descriptive research design of ex-post-facto type. The study presents findings from available literature on the subject and offer new ways of looking at graduate employment in Nigeria, especially with regards to public policy.

\section{The Labor Market in Nigeria}

A labor market can be understood as the mechanism through which human labor is brought and sold as a commodity and the means by which labor; the number and type of available jobs is matched with labor supply; the number and type of available workers (Grimshaw et al., 2008). Hence, the labor market constitutes the systematic relationship that exists between workers and work organizations. In order to achieve its strategic objectives, a fundamental concern for an organization is to ensure that it has the right people with the right skills, knowledge and attributes in the appropriate positions. There are two approaches a firm may adopt to acquiring the required labor.. First, a firm may train existing employee (internal) and retaining their services over the long term. Second, the firm may recruit the required labor from outside (external) the firm as and when needed. Most of the firms in Nigeria adopt both methods to recruit the required labor. The external labor market represents the external supply such as the new university graduates or available stock of labor. This type of labor a firm requires and the potential pool of workers available is determined by the industry sector in which the organization operates, its central activities, its location, size and scope and its competitive strategies. A firm's external labor market can be local, regional, national or international and many large organizations will operate in all of these depending on the type of labor sought and its relative scarcity.( Kalleberg, 2003). Labor market can be analyzed according to the distribution of skills, knowledge, educational achievement and occupational group. The labor can also be viewed as being segmented according to worker characteristics such as age, gender, ethnicity, disability, cultural background or attitude ( Grimshaw et al., 2008).

Nigeria has the potential for rapid economic growth and development given her rich human and material resources. Yet the economic performance of the country has been described as erratic, dismal, truncated and largely unimpressive ( Ajayi, 2002, lyoha and Oriakhi, 2002; Kayode, 2004; Ekpo, 2008). The poor growth performance of the economy is reflected in the increase in poverty, massive graduate unemployment, skyrocking inflation, worsening balance of payments, dis equilibrium, monumental external debt, widening income disparity and growing fiscal imbalance which taken together constitute Nigeria's crisis of underdevelopment (Bassey and Atan, 2012) 


\section{The Labor Market and Graduates in Nigeria}

Employment is the basic labor market outcome of education for individuals. There are three fundamental ways in which education affects this outcome (Fasih, 2008). First, those with fewer skills, less knowledge and fewer degrees are less attractive to potential employers and less prepared to start their own business. Second, individuals who followed a vocational or technical education track will enter different occupations from those who followed a general education track. A third way in educational attainment affects employment is by ensuring greater earnings within an occupation ( although much depends on the quality of education as well).

The link between higher education and the labor is evidenced by organizations such as the Oil and the Medical industries which require highly trained graduates such as engineers, scientists and doctors for their organizations to function properly. The word graduate is used broadly in this study to refer to individuals with post matriculation qualification or tertiary diploma or certificates ( Pauw et al, 2008). In all modern economies, universities are places where specialized human resources are developed. Therefore, they play a crucial role in generating human capacities for leadership, management and technical expertise. In today's world where knowledge based economies that have emerged following globalization and information technology revolution, universities are expected to play a pivotal role by generating, harnessing and transmitting knowledge for sustainable development and improved standard of living. Table 1 presents a bleak picture of employment prospect for university graduates in Nigeria since they belong to the professional and executive cadre. In 1990, although 10,182 applied for jobs, only 3,695 vacancies were declared, out of which 986 (9.6\%) were recruited. The situation was worse in 2000 (eleven years later) when 104,960 registered unemployed applied for 115 vacancies, of which only 110 were recruited. It is noteworthy to mention that whereas the number of registered unemployment was soaring high overtime, the number of declared vacancies was reducing steadily indicating the crippling nature of the Nigerian economy.( Bassey and Atan, 2012). It should be noted that there were many unemployed graduates who did not bother to register.

Table 1: Registered unemployed and vacancies declared (professional and executives) 1990-2004

\begin{tabular}{lccccc} 
Year & Registered & $\begin{array}{c}\text { Vacancies } \\
\text { declared }\end{array}$ & Placement & $\begin{array}{c}\text { \% of Placement } \\
\text { to vacancies }\end{array}$ & $\begin{array}{c}\% \text { of Placement to } \\
\text { registration-- }\end{array}$ \\
\hline 1990 & 10,182 & 3,695 & 986 & 26.6 & 9.6 \\
1993 & 108,153 & 12,605 & 79 & 0.001 & Negligible \\
1995 & 32,442 & 3,708 & 49 & 1.3 & do \\
1998 & 99,376 & 38 & 2 & 5.3 & do \\
2000 & 104,960 & 115 & 110 & 95.7 & do \\
2001 & 84,359 & 127 & 93 & 73.2 & do \\
2002 & 94,663 & 121 & 102 & 84.3 & do \\
2003 & 61,961 & 917 & 657 & 71.6 & 1.1 \\
2004 & 87,731 & 617 & 510 & 82.7 & 0.005 \\
\hline
\end{tabular}

Table 1 is instructive for the following reasons. It illustrates the fact that there are no jobs for graduates of higher education. Then, where are the jobs or why there are no jobs for the teeming graduates leaving the university armed with considerable knowledge? Graduate unemployment in has aroused considerable concerns because it represents a colossal waste of Nigeria's manpower resources. It generates welfare loss in terms of lower output, thereby leading to lower income and well-being ( Obadan and Odusola, 2003). Gbosi (2006) defined unemployment as a situation in which people who are willing to work at the prevailing wage rate are unable to find jobs. A broader definition is provided by the International Labor Organization (ILO) cited by Akintoye (2008) as, the unemployed is a member of the economically active population who are without work but available for and seeking for work including people who have lost their jobs and those who have voluntarily left work. Graduate unemployment imposes socio-economic costs: it is a waste of manpower resources, the investment in education and training that is not used.

\section{Determinants of Graduate Unemployment}

Graduate unemployment is an undesirable circumstance that beneficiaries of higher education involuntarily find themselves and it should be redressed. Many studies have been carried out on the unemployment situation in Nigeria, such as ( Dabalen et al.; 2002), youth unemployment (Uwen and Ndem, 2012), higher education and the demand for manpower (Ugwonah and Omegie, 1998) and labor market distortions (Godwin and Johnson, 2012. This study singles out the graduate unemployment in the labor market in Nigeria for critical analysis and emphasizes the socio-economic implications. Studies such as Folayan (1979), Fajana (2000) and Diejomaoh (1979) show that graduate unemployment in 
Nigeria was not a serious problem before and after the civil war (1967-1970). However, the situation has changed greatly from the late 1970's till date,, especially with the establishment of many private and more federal universities to satisfy the nation's education aspirations. The enrollment and turn-out of graduates have exploded annually without corresponding changes in the structure of the Nigerian economy. The economy should be massively diversified towards labor intensive industries to realize more employment. Industrialization and manufacturing have insignificant contribution to the national economy. Successive governments in Nigeria failed to diversify the economy away from its over dependence on the oil sector, which provided 95 per cent of foreign exchange earnings and about 80 per cent of budgetary revenues (Oreopolous et al, 2012). Thus, the policy environment for economic growth has not been favorable for many years. Many university graduates are produced than the economy can absorb and has resulted in graduate unemployment. Because so many people in whom the public resources have been invested are idle or unproductively utilized, the social costs to the nation are enormous ( bassey and Atan, 2012). Full employment will result in high productivity, increase national competitiveness in terms of penetration of world markets, since it indicates optimal capacity utilization of human and material resources ( Ashimuneze, 2011). Such a situation will reduce unemployment, increase income and improve the standard of living and socio-economic development.

A labor market such as that in Nigeria, generation of productive employment opportunities is the key to rapid and sustainable economic development. Low levels of employment generation do not only result from but also contribute to low aggregate demand and can therefore intensify tendencies towards stagnation and recession (Sodipe, 2011). The understanding and critical analysis of the impact of public policies to employment generation cannot be more important for Nigeria.

\section{Labor Market Demands for University Graduates}

The demand for labor is derived from production and distribution activities in the goods and services sectors. As a result, its size and shape are sensitive to what happens in the national economy ( Dabalen et al, 2000). The factors of production which are derived from manufacturing, which create jobs are absent in Nigeria. Hence the demand for labor in the Nigerian economy has been poor and volatile at best. Underinvestment in cocoa, oil palm, rubber, cotton, cassava, cashew, pineapple, rice, groundnuts and other cash crops has worsen the unemployment situation in Nigeria. Agriculture and rural development strategy can curb rural-urban migration (Martins, 2009). Graduate unemployment in Nigeria is the bane of public policy. It has hobbled economic growth and poverty reduction efforts. Public policy has a direct impact on agriculture, health and unemployment. For example, consider the government policy on infrastructure. Investment in infrastructure stimulates economic activities which generate employment opportunities. Improvement in infrastructure such as roads, railways, electricity, communications, water, housing, health and education infrastructure implies a reduction in unemployment.

An analysis of the causes of unemployment in Nigeria include among others, policy inconsistency and poor governance (NISER, 2010). Nigeria is presently underutilizing its manpower capacities relative to its potential for significant development. Graduates are produced at a geometric progression while the labor market is stagnant or at best grows at arithmetic ratio. The major growth drivers of the labor market particularly, agriculture and manufacturing continue to be weak and the required costs of the expected infrastructure needs of the labor market remain a major challenge to public policy. The root causes of graduate unemployment in Nigeria are structural and policy determined. The most prominent structural factor is the failure to improve the generation of electrical power. The second factor concerns policy failure and distortions in job creation. Nigerians are among the people most deprived of grid based electricity in the world. Nigeria has a per capital consumption that is far lower than many other African countries. A South African is provided 97 per cent more electricity than a Nigerian, while a Brazilian enjoys 93 per cent more. With a population of about 170 million, Nigeria's generation capacity is around 3,600 megawatts of electricity. South Africa generates $40,000 \mathrm{MW}$ for 50 million citizens. Brazil is able to generate 100,000 MW of grid based electric power for a population of 201 million people (President Task Force on Power).

Epileptic electrical power supply with the attendant effects on industrial production has hindered the expansion of the labor market. Electricity outages have forced many factories to fold up due to high production costs. Some firms such as like Michelin and Dunlop, firms that produce tires, moved their factories from Nigeria to Ghana in 2007, thereby creating unemployment for its Nigerian workers. The high cost of production that results from inadequate infrastructure has led to the collapse of the manufacturing industry in Nigeria. The implications for Nigeria is the high graduate unemployment and increase in criminal activities. Another causality of the erratic electricity power supply is the cement industry. Nigeria has abundant raw material for the production of cement that could employ many labor. Yet, N250 billion 
is spent annually on cement importation because Nigeria can produce only two million metric tons of cement for a population of 170 million people.( Ndujihe and Kunle, 2013). Nigeria will never realize its potential for economic prosperity unless the electricity question is addressed, like other infrastructure issues.

\section{Conclusion}

Higher education is an important catalyst for improving the livelihood of individuals. However, the right public policies need to be in place to create effective demand for graduates in the labor market. If for instance, the education system has given individuals the opportunity to achieve good quality higher education, it is important that the labor market is positioned to benefit from the knowledge of the graduates. In addition to higher education, good labor market opportunities for graduate require an economy to be operating well with economic stability. The findings of this study have major policy implications. Since employment generation for graduates is desirable for the growth and development of the labor market, there is need for public policy framework which is aimed for employment generation in all sectors of the economy. Thus, a coherent approach to graduate employment policy is advocated as a matter of urgency. There is considerable need for attention to infrastructure and agriculture for job creation. Otherwise, the Nigerian dream of a good education and a good job, thereafter, where there is some security will continue to be mirage.

\section{Recommendations}

The study recommends regional integration as the nexus for job creation for the higher education graduates in that region. For example, the South- South region is one of the most productive ecosystems in Nigeria. The region consists of Bayelsa, Rivers, Akwa Ibom, Cross River, Edo and Delta States. They are also collectively known as the Niger Delta. These are the oil producing States that support the Nigerian economy. This region through its rich petroleum oil and natural gas deposits, account for over 98 per cent of Nigeria's foreign exchange and this position has remained so since the early 1970s ( Omofonmwan and Odia, 2009). Therefore, this region has the financial resources to develop itself industrially. What is required is the cooperation of the leaders to work together with specific policy objectives of creating jobs for the teeming graduates of this region. These States can forge ahead with industrial development in this region, instead of waiting for the federal government

Richly blessed with a variety of natural resources, it treasures an abundant array of mineral, water and forest resources of immense economic potentials. There are abundant solid mineral resources that are still largely untapped. Exploitable solid minerals found in the region include sand, clay, salt, limestone, coal, silver nitrate and others. Among the lot, sand, clay and salt seem to gain prominence but are still largely underutilized. Sand is used for land reclamation, brick making and is the raw material in the glass industry. It has great economic potentials which if well-developed could support industrial activities and create employment opportunities for the higher education graduates in this region. At present, only one known glass factory exist in the region. It is located at Ughelli, Delta State, more could be built. Large deposits of fine, kaolinite clay are found throughout the region. This mineral with its potential in ceramic and pottery industries is still largely untapped. A ceramic industry was established in Akwa Ibom State because of the large commercial deposit of this mineral there; more could be built in other locations.

This region is blessed with abundant soil resource with extensive available farmland which supports subsistence agriculture and has enormous potential for agro based industrial development. In every part of this region, the available farmland supports the production of a variety of food and cash crops including cassava, yams, cocoyam, rice, maize, plantain, palm oil, raffia palm, coconut, cocoa, mango rubber and others. These major food and cash crops are in high abundance and they could be processed into products for local export markets or they could serve as raw materials for a variety of agro based industries. For example, cassava is widely grown in the region, mostly for garri, starch and tapioca. It is a raw for industrial starch, which could serve the needs of textile, drug and paper industries. Thus, extensive cassava farming, processing and industrial applications for local need and export thus represents a viable investment potential which needs to be utilized. Oil palm trees are abundant in this region and this cash crop provides a potential for large scale investment in palm oil processing and allied industries for both local and export needs, Oil and kernel derived from oil palm are high demand raw materials for various industrial applications, including foods, cosmetics, detergents, industrial oils and others. Rubber is a common tree crop in most part of this region. It grows as a forest resource and also is grown in plantations. There is a great demand for latex from rubber for production of plastics and glue for the wood and paper industries. Rubber latex is also useful in tire manufacturing. The development of rubber cultivation and production would provide raw materials for local rubber processing factories and for the export market. There are still other 
resources not mentioned here. The leaders in this region should not shy away from consulting with foreign partners for advice on using these abundant raw materials for industrial development that would expand the labor market and create employment opportunities for higher education graduates.

\section{References}

Ajayi, S. I .( 2000). Institutions the missing link in growth process. In: Proceedings of Nigeria Economic Society (NES). Annual Conference, pp. 1-22

Akintoye, I. R. (2008). Reducing unemployment through informal sector: A case study Of Nigeria. Europ. J. Econ. Finan. Admin. Sci., 11: pp. $97-106$

Ali, A. (1988). Vasities as agents of National Integration. National Universities Commission. Annual reports. Lagos: NUC.

Anugwon, E. E. (2009). Women, education and work in Nigeria. Educational Research and review. Vol 4(4), pp127-134

Ashinuneze, H. (2011). Developmental Retardation and Graduate Unemployment in Nigeria. www.utexas.edu/conference/ africa/870.html

Balami, D. (2003). Finance of Education in Nigeria. Paper presented at the forum on cost and finance of education in Nigeria. Abuja.

Bassey, G. E. and Atan, J. A. (2012). Labor distortions and university graduate unemployment in Nigeria. Current Research of Economic Theory. 4(3): pp67-76

Connor, D. Y. (1957). An Introduction to the Philosophy of Education> London: Routledge and Kegan Paul

Dabalen, A., Omi, B., Adekoka, O. (2000). Labor market prospects for University Graduates in Nigeria. Higher Education management. Vol. 14, pp1-36.

Diejomoah, V. P.(1979). Unemployment in Nigeria. An Economic Analysis of Scope, Trends and Policy Issues. Nigeria Journal of Economic and Social Studies. Vol. 13(2). Pp.127-160

Ekpo, A. H. (2008). The Nigerian economy: is it at the cross road? In Presidential Address at the NES Annual Conference. Pp: 67-105

Fajana, S. (2000). Functioning of the Nigeria labor market. Labofin and Company, Lagos, Nigeria

Folayan, O. (1979). Causes of Graduate Unemployment in Nigeria. International Labor Organization.

Fasih, T. (2008). Linking Education Policy to Labor Market Outcomes. Work Bank. Washington. D.C.

Godwin, E. B. and Johnson, A. A. (2012). Labor market distortions and university graduate unemployment in Nigeria. Issues and remedies. Research journal of Economic Theory. Vol. 4. No3, pp67-76

Grimshaw, D, Ward, K. Rubery, J. and Beynon, H. (2008). Organizations and the transformation of the internal labor market. Work, Employment and Society 5(1). Pp25-54.

Iyoha, M. A. and Oriakhi, O. (2002). Explaining African economic growth performance: The case of Nigeria. Afr. Econ. Res. Consort. 23(1): pp1-65

Kalleberg, A. L. (2003). Flexible firms and labor market segmentation. Effects of workplace restructuring on jobs and workers. Work and Occupations 30(2): pp154-75

Kayode, M. O. (2004). Towards a Re-Birth of Nigeria's Economic Development. In Fouth Annual Public lectures, NES, pp3-37

Martins, R. (2009). Are there lessons for Africa from China's success against poverty. World Development report (WDR). Vol. 37(2). Pp303-313

NISER (2010). Unemployment in Nigeria. A Situational Analysis, Human Resources Development Department. ISBN 9789781813636 : pp163

National Policy on Education (2004). Federal Government of Nigeria. Abuja

Ndujihe, C. and Kunle, K. (2013). Nigeria: Epileptic Power Supply. http://allafrica.com/stories201304140133.html.

Obadan, M. I. and Odusola (2003). Productivity and Unemployment in Nigeria. Nigeria Institute of Social and Economic Research (NISER), Ibadan

Odaro, I. O. (2013). Nigeria, Educational System. Needs to be Revolutionized. http://nigeriaobservernews.com

Omofonmwan, S. I. and Odia, L. O. (2009). Oil exploitation and conflict in the Niger delta region of Nigeria. Journal of Human Ecology 26(1), pp25-30

Oreopolous, P., Von Watcher, T., and Andrew, H. (2012). Short and long Term Career Effects of Graduating in a Recession. American Economic Journal; Applied Economics

Pauw, K., OOsthuizen, M., and Van der Der Westhuizen, C. (2008). Graduate unemployment in the face of skills shortages. A labor market paradox. S. Afre. J. Econ. 76(1): pp45-57

Sodipe, O. (2011). Employment and economic growth nexus in Nigeria. Internation Journal of Business and Social Sciences. VOL 11, pp232-239.

Stephen, M. (1992). Poverty, Population and the Environment. World Development Report. The World Bank. Washington, D.C.

Ugwonah, G. E. and omeje, K. C. (1998). Higher education and the demand for manpower development in the Nigerian manufacturing sector. An Empirical Study of Enugu and Anambra States. In Trace Studies Research report. Pp55-72

UNESCO (2008). National Education Support Strategy for Nigeria 2006-2015. Abuja

Uwem, E. and Ndem, A. (2012). Jobless growth, the action poor phenomenon and youth unemployment in Cross Rivers State, Nigeria: Learning points from Europe 2020 flagship initiative. Agenda for New Skills and Jobs. Science Journal of Economics. Volume 2012, Article ID sje-108, 16 pp. DOI: 10.7237/SJE/108 